\title{
Personal Hygiene Behavior of Butonese Adolescent Females during the Posuo Ritual in Baubau
}

\author{
Sri Wahyu Safitri Adkar ${ }^{1 *}$, Suriah ${ }^{1}$, Stang ${ }^{2}$, Muhammad syafar ${ }^{1}$, Masyitha Muis ${ }^{3}$, Healthy Hidayanthy ${ }^{4}$ \\ ${ }^{1}$ Department of Health Promotion, Faculty of Public Health, Hasanuddin University, Indonesia \\ ${ }^{2}$ Department of Biostatistics, Faculty of Public Health, Hasanuddin University, Indonesia \\ ${ }^{3}$ Department of Occupational Health and Safety, Hasanuddin University Indonesia \\ ${ }^{4}$ Department of Nutrition, Hasanuddin University, Indonesia \\ *Corresponding Author \\ Sri Wahyu Safitri Adkar
}

Abstract: Butonese people have posuo tradition, a ritual or ceremony that marks a transition of girls who have entered puberty. In this tradition, young women are locked up for eight days. This study discusses the importance of personal hygiene of Buton tribal girls in supporting the posuo tradition in Baubau, Buton Island. This study is a qualitative study with rapid ethnographic approach. We used purposive sampling with a total of 14 informants. To help young women relate to personal hygiene in implementing the posuo tradition, the data were analyzed by thematic techniques and the validity of the data by triangulation approach. The results of this study are the posuo tradition, which is a ceremony held as a means to mark the transition period of adolescent girls to adulthood, and to prepare them mentally. Posuo is conducted eight days in a special room called suo. During their confinement in suo, the girls were kept away from the outside world, both from their families and the surrounding environment. These girls are only allowed to communicate with bhisa. This study which included seven adolescent girls showed how they acquiesce personal hygiene for the sake of traditional processions. The results of the study are expected to give the implication of the need for education from health workers about personal hygiene, with the specific targets of Buton tribal girls. Keywords: health behaviors, posuo, norms, personal hygiene, traditions.

\section{INTRODUCTION}

Personal hygiene in adolescents is a critical problem as a determinant of the health status of adolescents who will play a role in old age life. Poor personal hygiene may lead to morbidities and

complications (Uzochukwu, 2009). Therefore, adolescents must be prepared with knowledge about the right hygienic behaviors to achieve healthy reproduction.

Personal hygiene is a behavior to maintain one's cleanliness or health to get physical and psychological well-being. Health care and hygiene are widely discussed in society. Hygienic habits, including cleansing sexual organs is part of general personal hygiene (Lestari, 2011; Isro'in and Andarmoyo, 2012).
Personal hygiene is self-care carried out to maintain physical and psychological health. Understanding of self-care is affected by several factors, including culture, social values in individuals or families, knowledge, and perceptions of self-care (Hidayat and Uliyah, 2008). In some cultures, it is believed that individuals with certain illness are not allowed to be bathed (Department of Health, 2010).

According to Honigman in Koentjaraningrat (1985), tradition is part of the culture that exists in society, which is interpreted as a habit, which has long been carried out and passed down from generation to generation, both verbally and in writing in forms, that is held as a form of activity. Several studies about tradition and culture that have rituals related to personal hygiene in young women have been conducted both in Indonesia and abroad.

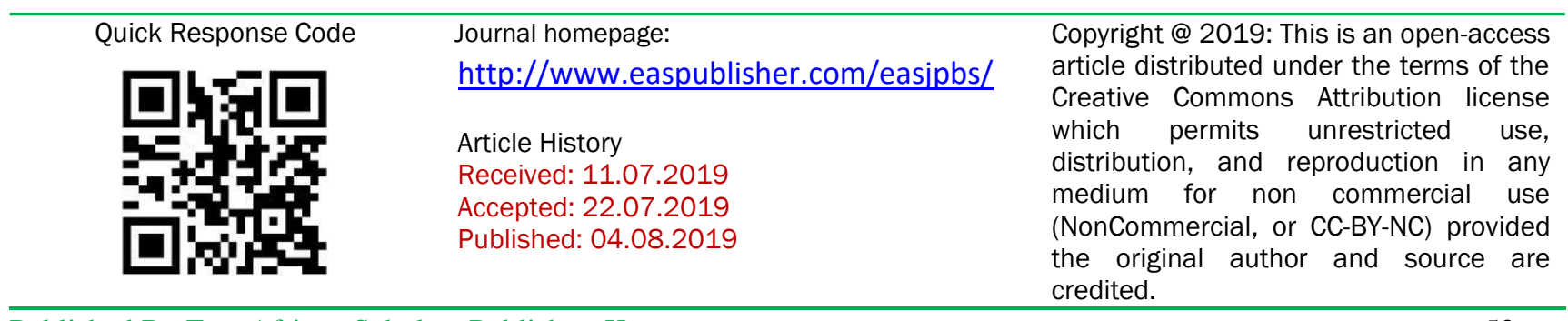


Southeast Sulawesi Province has a variety of local tribes including the Tolaki tribe, Buton tribe, Muna tribe, Bajo tribe, Javanese tribe, Ambon tribe, and Bugis tribe which each has different beliefs and traditions. The Buton tribe is one of the tribes that inhabit the territory of the Buton Sultanate. The Buton Sultanate is located in the Bau-bau archipelago of Southeast Sulawesi. The ancestors of the Butonese came from immigrants who came from Johor around the $15^{\text {th }}$ century and later established Buton kingdom. This kingdom lasted until 1960 where the last sultan died. After the death of the last sultan, the traditions of Buton archipelago started to be left behind (Schoorl, 2003).

Of the many cultures found in Baubau, there is posuo tradition, a seclusion ceremony which determines the transition of status of an individual (female), from a teenage girl (kabuabua) to an adult woman (kalambe). Posuo is held for girls aged 14-19 and is aimed to deliver physical and mental preparation for a future married life (Interv, ED, 27 Dec 2018).

There are three types of posuo: posuo wolio, posuo johoro and posuo arabu. Posuo wolio is the type of posuo from the Wolio or Buton community itself, posuo johoro is from Johor-Melayu and posuo arabu is an adaptation of posuo wolio that contains Islamic values. When a girl is in posuo, she will be isolated and kept away from various influences of the outside world. The girl can only communicate with bhisa. Bhisa is a person who is directly appointed by indigenous stakeholders to provide various counsels during posuo (Iffa, 2016).

The objective of posuo is to prepare adolescent girls physically and mentally for their future role as married women. This is done by alienating them for a certain period of time from the lives of wide community (Munafi, 2014).

Personal hygiene is one of the main health concerns in in posuo since the girls are not allowed to bathe for four days, are only allowed to wear a piece of fabric that cannot be replaced until the fourth day, in which the new fabric is also worn until the last day of posuo (day 8). In addition, the prohibition of bathing during seclusion will be a problem for health behaviors, especially personal hygiene, including the cleanliness of genital area that is susceptible to various diseases.

In the 2017 Pythagoras study, it is said that not changing underwear at least two times a day is an improper treatment of vaginal area. In addition, sanitary pads that aren't changed one to more than five to six hours after urination, defecation and bath can cause infection of reproductive organs. As shown in a study conducted by Sapkota et al in 2013 in rural Nepal, the majority $(67.2 \%)$ of respondents said that sanitary pads were ideal for menstruation, but only $54.1 \%$ used it.
Nearly half of women $(50.8 \%)$ replaced sanitary pads twice a day. The majority of respondents $(62.3 \%)$ did not believe that maintaining personal hygiene was related to menstrual problems.

In several developing countries, 2013 WHO data showed that the prevalence of correct application for personal hygiene is $6-27 \%$ of the general population. In Indonesia, the prevalence is $4.60-12.5 \%$ (2010). In US, personal hygiene problems are the third leading cause of death in children in 2001. In Indonesia, the incidence rate in 2008 reached $60-80 \%$ and mortality rate reached $4 \%$ and affected mainly age nine to twelve. Personal hygiene cases occupy the second place (11\%) in pediatric medicine after acute respiratory tract infection (ARTI). Every year, an average of 100 children die due to poor personal hygiene (Thoyyib, 2016).

The 2012 Indonesian Demographic and Health Survey (IDHS) for Adolescent Reproductive Health (ARH) revealed that adolescents' knowledge about reproductive health is inadequate. The prevalence of reproductive tract infections in Indonesia due to lack of hygiene in genital organs is still quite high, which is about 90 to 100 cases per 100,000 population per year (Ministry of Health, 2013).

Lack of self-cleansing behaviors cause adolescents to be susceptible to infection of reproductive organs. As proven by Bano et al in their 2015 study at the Arab University, although $80 \%$ of the girls knew that maintaining personal hygiene could prevent health problems and pain, only $62 \%$ applied a satisfying hygiene routine. The overall score for knowledge about reproductive health and hygiene was found to be $54 \%$. The study also highlighted that women must have the correct knowledge about their reproductive health to protect them from diseases. It is a well-known fact that reproductive health is very important for one's health in general because it paves the way for future generations.

According to Bujawati's study (2016), good personal hygiene is also influenced by individual beliefs about local myths that it forms a relationship between myth-based knowledge about menstruation and personal hygiene during menstruation. Whereas in a study by Dolang et al in 2016, it is stated that personal hygiene behaviors were influenced by maternal education, knowledge, role of mass media, family's social economic status about the practice of menstrual hygiene.

How close posuo tradition is with daily lives of Butonese people is what made the author interested in conducting this study. Posuo, as a sign of a woman's transition from adolescence to adulthood by alienating herself from people and the surrounding environment to reflect on her life and future and learn to improve 
herself to be better for her future married life, requires several rules in its implementation such as the prohibition of bathing and the use of only turmeric and rice as a form of personal hygiene and the prohibition of sarong changing worn by young women during in suo. It interested the author in conducting a study related to posuo ritual in Buton Tribe by exploring how the personal hygiene behaviors of Butonese young women in posuo tradition in Baubau.

Posuo ritual, or as called pingitan in Indonesian language, is carried out for four to eight days where the adolescent girls are isolated and kept away from their families, surrounding community and the outside world and are taught about matters relating to women's personalities and household skills under the guidance of several traditional female leaders called bhisa.

Posuo is consisted of three sessions, namely malona tangia (night of sobs), yimpo bhaliana and matana karia. Posuo ritual begins with the pauncura or inauguration of the participants by senior bhisa called parika by burning incense which is then followed by citing prayers, explanation of the ritual and the rules in suo, citing the names of the participants and then followed with sweeping the incense smoke onto the bodies of the girls (phanimpa). Right after the names of the participants were mentioned, the girls should begin to be silent and cry, and if they are not able to cry, they will be pinched or beaten in certain parts of the body to trigger crying because it is believed as a bad sign for their future. Some participants said they were crying because they were happy that their parents had done one more responsibility for their daughters by holding this ritual. This session is called molano tangia or the night of sobs.

All the rules in suo should be strictly obeyed. Traditionally, the girls are required to wear only sarong during their time in suo. This does not have a specific meaning, it is just to make it easier for participants to rub grated turmeric and rice evenly throughout their bodies. The use of turmeric lasts until the fourth day, then on the fifth day it is replaced with the use of mashed rice. The turmeric and rice concoction should be made using the water that has been cited by bhisa with prayers before it can be smeared onto the faces. This concoction should be applied in the morning, afternoon and evening. During their time in suo, the girls are forbidden to see their reflection in the mirror, meet the opposite sex, comb their hair, take a bath and use a fan. The suo has a long cloth (wolio netting) installed wrapping the room or attached to the surrounding walls of the room. This implies the secretful meaning of posuo because the participants should not be seen by people, especially the opposite sex. During the session, phanimpa is done twice daily, in the morning and in the evening. This symbolizes a form of neutralization, it is also to help preventing frequent defecation. The participants are prohibited from standing up and leaving their mats. The mat acts as a barrier for the participants, and they have to move by dragging their buttocks. If the bathroom is separated from the suo, then if one the girls need to visit the bathroom to defecate, she has to cover her head and face using a sarong and move by dragging her buttock on the floor.

Matana kariya is the highlight of the posuo ceremony that occurs on the eighth day. This event starts in the afternoon with a single ritual activity, namely bathe (pebhaho). The girls will be congratulated by the family, relatives and friends, and invited guests for finishing posuo and becoming adult women. This last session starts with procession of bathing the participants (phaebo) using a water container made of clay (bhosu) in which the participants still are still wearing their sarongs (timbasa) that later cannot be used again for life (usually it is thrown away to the sea) in the hope that all their sins and blemishes in their adolescence are thrown away so they become better as adults. After bathing, the girls are dressed in Butonese traditional clothes for adult women (kalambe) and taken to the inauguration site to get formalized as adult women. The inauguration is carried out by the wife of an official of the Great Keraton Mosque (moji). The girls will have their sole smeared with dust (soil) which marks the end of their adolescent lives and the beginning of their adult lives.

\section{METHODOLOGY \\ Research Design}

The type of study used was qualitative study with rapid ethnographic approach. This research was carried out in City of Baubau, Southeast Sulawesi Province in 2019.

\section{Population and Samples}

The informant selection technique used purposive sampling based on the inclusion criteria that had been determined. The informants consisted of traditional leaders, community leaders, teenage girls who had done posuo and their mothers, and health workers, totaling 14 people.

\section{Data Collection}

Secondary data is obtained by gathering information and documents from books, articles, and researched journals.

Primary data is obtained by conducting in-depth interviews with each informant by asking questions in the form of interview guidelines.

\section{Data Analysis}

Data analysis used thematic techniques, which is a technique used by searching for themes that appear in research data. 


\section{Focus and Description of Focus}

The author focused on examining personal hygiene behaviors of young women in the implementation of posиo tradition of Butonese community. Posuo rituals can be carried out for one day, four days or eight days, but author focused the study on the implementation of eight days posuo. Description of focus is explained below. (1) Posuo tradition, adulthood rituals for women, which aim to divert a woman's status from childhood to adulthood. The process of implementing this ceremony is divided into 3 stages namely (1) malona tangia, (2) bhalia yimpo, and (3) matana kariya. (2) Personal pygiene behaviors, how young women behave during posuo in correlation to personal hygiene. This behavior is influenced heavily by beliefs and norms about personal hygiene applied in posuo tradition.

\section{RESULTS}

Baubau is one of the cities in Southeast Sulawesi. Baubau is located in Buton Island. Buton Island is known as the largest asphalt producer in Indonesia and with the largest palace fortress in the world. Based on the 2017 population projection, the number of population in Baubau is 162,780 people consisting of 80,371 male and 82,409 female (BPS, 2018).

In terms of ethnicity, Baubau has a homogeneous population where the majority of the population is the Buton tribe. This was due to the fact that the city is the center of the government of the
Sultanate of Buton at the past. The ethnic population other than the Buton tribe who have settled in the city is due to marriage or state duties.

The Buton tribe community in the kingdom was classified into three groups, namely kaumu, walaka, and papara. Kaumu and walaka were the groups that controlled the government and lived in the palace, while papara were common people who inhabited kadie.

Table 1 Characteristics of Buton tribal teenage girls as informants

\begin{tabular}{|c|c|c|}
\hline Initial & Age (years) & Education \\
\hline KK & 25 years & S1 \\
\hline EW & 24 years & S1 \\
\hline PAL & 23 years & S1 \\
\hline SSR & 24 years & D3 \\
\hline PAC & 24 years & S1 \\
\hline WNA & 23 years & D4 \\
\hline NA & 17 years & High school \\
\hline
\end{tabular}

Table 1 shows the characteristics of the main informants, namely adolescents who carried out 8 days posuo, with the age varied from 17 to 25 years old and education level of high school, D3, D4 and S1 $(n=7)$.

Table 2 shows the characteristics of supporting informants who are parents of the young women, indigenous people, community leaders and health officers $(n=7)$.

Table 2 Characteristics of supporting informants

\begin{tabular}{|l|c|c|l|}
\hline Initial & Age (years) & Education & \multicolumn{1}{c|}{ Role } \\
\hline HT & 55 years & High school & Supporting informant (parent) \\
\hline HN & 43 years & High school & Supporting informant (parent) \\
\hline US & 68 years & Middle school & Key informant (bhisa) \\
\hline NS & 63 years & Bachelor & Key informant (traditional leader) \\
\hline SS & 60 years & Magister & Key informant (community leader) \\
\hline WH & 33 years & D3 & Key informant (traditional leader) \\
\hline HPS & 31 years & Bachelor & Key informant (health worker) \\
\hline
\end{tabular}

\section{Beliefs}

According to Theory of Reasoned Action (TRA) by (Sheppard et al., 1988), practice or behavior is influenced by intention, whereas intention is influenced by subjective attitudes and norms. Attitude itself is influenced by the belief on the results of past actions.

The WHO theory analyzes that what causes a person to behave in a certain way is thought and feeling in the form of knowledge, perception, attitude, belief and judgment of an object (object of health). Trust is often obtained from parents or grandparents. A person accepts beliefs based on faith and without proof first (Notoatmodjo, 2014).
Based on the results of this study, the informants stated that their personal hygiene behaviors during posuo were influenced by beliefs that had been taught and had become hereditary. The customary rules made the behaviors of young women towards personal hygiene limited. The rule of not changing the sarong for four days, prohibition of bath, dragging buttock to move made the young women reluctant to change their underwear because they found it troublesome. It then led to itching in the vaginal area, vaginal discharge and irritation due to the use of turmeric. The limited time given to these girls to clean themselves during menstruation and changing the sanitary pads for the average two times a day resulted in itching in the vaginal area due to prolonged use of sanitary pad. 
Based on the rules related to the beliefs that are applied in posuo tradition, it automatically limits the perspectives of the Butonese women in terms of beliefs about personal hygiene. These women consider that the posuo tradition does not have negative impacts on health. They believe that using turmeric and rice on the body and the face is enough to keep themselves clean because it can eliminate body odor and brighten their skin since they used turmeric and rice as scrubs.

The use of turmeric and rice is believed by Butonese can help eliminate body odor and brighten facial skin, even though they don't know the exact content of turmeric and rice. Based on health science, in fact turmeric does have many health benefits for health and skin care. Due to its antioxidant content, turmeric can help the skin regeneration process, while reducing the formation of black stains on the skin, zits and other skin problems. In addition, the use of rice in caring for the skin turns out to also have benefits, because rice contains natural antioxidants such as vitamins $\mathrm{C}$ and $\mathrm{A}$, phenolic, and flavonoid compounds, which can minimize free radical damage from aging, sun, and environment. As long as the traces are still left on the skin, rice water is even believed to offer mild protection from sunlight. Rice also has properties that help to improve blood circulation, prevent or fade age-related black spots, and relieve inflammation to give a healthy skin appearance, moisturize and brighten the skin.

Turmeric contains curcumin which can accelerate wound healing. Curcumin can increase reepithelialization, suppress inflammation, increase tissue collagen density and increase proliferation of fibroblasts (Partomuan, 2009). The nature of turmeric that can heal wounds has been reported since 1953. It is showed that turmeric accelerated the rate of wound healing $23.3 \%$ in rabbits and $24.4 \%$ in mice (Ide, 2011).

The use of rice the care of young women while undergoing posuo apparently has benefits. Based on specific health sciences, the content of rice that is beneficial to the skin is tocols (tocopherol and

tocotrienol), gamma-oryzanol and ceramide. Tocopherol and tocotrienols are pure natural vitamin E. Vitamin $\mathrm{E}$ has been widely known as a beneficial antioxidant that is good for health. Gamma-oryzonal is a compound that is also useful as an anti-oxidant, protects the skin from UV, and is believed to be an anti-aging agent (Kayahara and Tsukahara, 2000). Medical experts stated that powdered rice can be applied to cure some forms of skin disease. On the Indian subcontinent, rice water is prescribed by ayurvedic practitioners as an ointment to heal inflamed skin surfaces (Umadevi et al, 2012).

According to WHO, trust is often obtained from parents or grandparents. A person accepts beliefs based on faith and without proving it first. Similar to the results of the study, it was found that the young women of the Buton tribe who underwent posuo believed that if they violated the rules in this tradition they or their family would have bad luck in the future.

This is in line with Puspitasari's study (2017) at SMAN 1 Megamendung Bogor, which found that there's a significant correlation between respondents' faith and beliefs with their personal hygiene behaviors. It showed that $63.7 \%$ of the adolescents had beliefs on the cultural leaders and $36.3 \%$ of them did not believe them. According to Ningsih's study (2017) Personal Hygiene Behaviors in Young Women of SMAN 1 Megamendung 205 , trust has an important influence on an individual's personality. If the beliefs or the surrounding culture are accustomed to maintaining cleanliness, the individuals will be trained on their own to maintain cleanliness.

Similar to study on personal hygiene conducted by (Santina et al., 2013), there is a significant correlation between menstrual hygiene practices of Lebanese adolescents with beliefs, sociocultural, religion, parents and level of education. Another supportive study is (Bujawati's et al 2016) that found that female religious beliefs in the Babul Khaer Islamic University of Bulukumba district had a correlation with their behaviors regarding menstrual personal hygiene.

The beliefs of the Buton tribe in relation to posuo tradition is in line with the belief of isolating themselves in Mesele's study (2018) in Ethiopia, especially in Raya Alamata region, where people still practice seclusion and exile as traditional maternal health practice to maintain health and ease delivery for women in South Tigray. These women are confined in a small place called Kuta. The majority of these women who are in delivery get locked up or should stay at home for one month to six months.

Based on this study, Butonese people's beliefs regarding posuo tradition are based on the faith that has been passed down from their ancestors to the next generations. As for the rules in posuo tradition (prohibition to defecate, being exposed to light, lift their buttocks from the floor which then lead them to be reluctant to change their underwears and sanitary pads, and should be locked up in a room where all the air circulation is blocked with wolio netting), they can lead to various health condition such as acute respiratory infection, vaginal discharge, cervical cancer, candidiasis, or other skin diseases.

\section{Norms}

Ajzen (2005) stated that subjective norms are functions based on a belief called normative belief, which is a belief regarding agreement and/or disagreement that comes from referents or influential people and groups for individuals (significant others) such as parents, partners, close friends, co-workers or others towards specific behavior. Subjective norms are 
defined as individual perceptions of social pressure to conduct or not conduct a behavior. Subjective norms are determined by a combination of individual normative beliefs and motivation to comply.

Subjective norms are influenced by the belief in the opinions of others and the motivation to obey that opinion. This theory states that someone will do an action if he or she views the action as positive and if he or she believes that someone else wants him or her to do it (Subaris, 2016).

Based on the results of interviews conducted with the informants about the custom norms in posuo tradition which impacted the behavior of personal hygiene, they said that they had some rules that existed in posuo tradition which must be adhered to especially young women during their time in suo, including being forbidden to lift their buttocks from the floor that they felt troubled to change their underwears, very limited time to change their sanitary pads for them who were bleeding, and prohibition to bathe and to change their clothing. The prohibitions during posuo are very closely related to personal hygiene behaviors.

Prohibition of bathing and eating food other than rice and eggs during posuo are aimed to teach the girls about modest marriage life. The wife must sincerely accept whatever the husband lack of, be patient, be by each other's side through ups and downs. There is also a rule of sleeping position that symbolizes fetal position in the womb. Every element in posuo is a symbol that contains philosophical meaning and values. These philosophical meaning and values are what the women should understand and implement (Nurluli, 2019).

Kusmiran (2014) explained the importance of maintaining self and clothes cleanliness. He explained that during menstruation women sweat more than usual, therefore, in order to stay fresh and free of body odor, one must take good care of his or her body by taking regular clean bath and washing hair at least once every two days. Poor body cleansing and clothing can impact on the growth of harmful microorganisms on the body.

As is the case stated by G. M. Foster 1973 that the norms applied in society greatly affect the health behavior of community members who support the norms (Foster, 2009). Based on the results of this study, it was also found that during posuo the girls were only allowed to eat a handful of rice and eggs, which was expected to teach young women to refrain from modern things and not to defecate during posuo, since defecation is seen as taboo. Speaking with loud voice is also a taboo during posuo.

Our results related to norms are in line with the study from (Dusra, 2019) in the Nuaulu tribe in Central Maluku. In their culture, there is a rule that prohibit bathing during posune, because the Nuaulu tribe believes that the pinamou's impurity and dirty blood is unclean that it can pollute the water that is also used by the Nuaulu tribe. They believe that to neutralize the impurities in the bodies, they must use the water from Nua river. Foster's theory (1973) supports the results of this study that norms in society greatly influence the behavior of the public in the health sector, because norms are viewed as good forms of behaviors.

\section{CONCLUSION}

Based on the research results, young women seem to tend to see personal hygiene as something that is taken for granted from the traditions of the previous generation, and beliefs related to rules are more dominant than maintaining personal hygiene. Customary rules and traditions carried out during posuo cause the young women to have limitations in positive behavior towards health. Posuo tradition leads them to sacrifice their personal hygiene for the sake of traditional procession. Therefore, it is expected that for the Health Service, counseling needs to be carried out regarding personal hygiene in particular regarding reproductive health both in the community and in schools. Therefore, it is expected that the health service to routinely educate community, mainly parents and traditional and community leaders, and adolescent girls at schools about the importance of maintaining personal hygiene, even when they are undergoing traditional procession.

\section{REFERENCES}

1. Ajzen, I. (2005). Attitudes, Personality, and Behavior. New York: Open University Press.

2. BPS. (2018). Kota Baubau Dalam Angka : Baubau Municipality in Figures. Catalog Central Bureau of Statistics (BPS) : 11022001.7472.Baubau : UD. Syahid.

3. Bano, R. \& Fatima AA. (2015). Study of Knowledge and Practice of University Females Regarding Reproductive Health and Hygiene in

Hail, Saudi Arabia. International Journal of Women's Health and Reproduction Sciences, 3(1):31-39.

4. Bujawati E., Sitti R. \& Indriyanti, (2016). FaktorFaktor Yang Berhubungan Dengan Personal Hygiene Selama Menstruasi pada Santriwati di Pesantren Babul Khaer Kabupaten Bulukumba Provinsi Sulawesi Selatan. Jurnal UIN Alauddin, 3(1):1-9.

5. Department of Health. (2010). Profil Kesehatan Indonesia Tahun 2010. Jakarta: Ministry of Health of the Republic of Indonesia.

6. Dolang, M. W., Rahma R. \& Muhammad I. (2013). Faktor Yang Berhubungan Dengan Praktik Hygiene Menstruasi Pada Siswi SMA Negeri 1 Sesean Kabupaten Toraja Utara. Jurnal MKMI Fakultas Kesehatan Masyarakat Universitas Hasanuddin, 9(1):36-44. 
7. Dusra, E. (2019).Perilaku Personal Hygieneremaja Putri Suku Nuaulu Dalam Tradisi Pinamu Di Kabupaten Maluku Tengah. Jurnal Ilmiah Kesehatan Diagnosis.14(1):31-35

8. Foster, A. (2009). Antropologi Kesehatan.editor. UI-Press: Yogyakarta. The Field of Medical Anthropology.

9. Hidayat \& Uliyah. (2008). Keterampilan Dasar Praktik Klinik untuk Kebidanan.Jakarta: Salemba Medika.

10. Ide P. (2011). Health Secret of Turmeric (kunyit). Jakarta : PT Elex Media Komputindo

11. Iffa A. (2016). Ritual Posuo Adat Kesultanan Buton Ditinjau Dari Hukum Islam: Studi Ritual di Kecamatan Murhum, Kota Baubau Sulawesi Tenggara (Skripsi). Jakarta : Universitas Islam Negeri

12. Isro'in \& Andarmoyo. (2012). Personal Hygiene; Konsep, Proses, dan Aplikasi dalam Praktik Keperawatan. Edisi Pertama. Yogyakarta: Graha Ilmu.

13. Kayahara H. \& Tsukahara K.(2000). Rasa, kesehatan, dan gizi kualitas pra berkecambah beras merah.International Chemical Congress of Pacific Basin Societies in Hawaii.

14. Ministry of Health. (2013). Riset Kesehatan Dasar (RISKESDAS). Jakarta: Health Research and Development Agency of the Republic of Indonesia.

15. Koentjaraningrat.,editor.(1985). Pengantar Ilmu Antropologi. Jakarta : Aksara Baru.

16. Kusmiran, E. (2012). Kesehatan Reproduksi Remaja dan Wanita. Jakarta: Salemba Medika

17. Lestari, N. (2011). Tips Praktis Mengetahui Masa Subur.Yogyakarta: Katahati.

18. Mesele, HA. (2018). Traditional Maternal Health Beliefs and Practices in Southern Tigray: The Case of Raya Alamata District.Anatomy \& Physiology: Current Research.8(298):1-12

19. Munafi, Laode A., \& Andi T. (2014). Tanah Wolio Dalam Bingkai Sejarah, Peradaban, Wacana, Dan Renungan. Makassar: Fahmis Pustaka.

20. Ningsih, RR.(2015).Tingkat Pengetahuan remaja Putri Tentang Personal hygiene di Desa Kwangsan Karangayar (Karya Ilmiah). Surakarta: Kebidanan STIKes Kusuma Husada.
21. Notoatmodjo, S. 2014. Ilmu Perilaku Kesehatan. Jakarta: Rineka Cipta.

22. Nurluli.(2019). Peranan Tokoh Adat Dalam Mempertahankan Adat Istiadat Posuo (Pingitan) Pada Masyarakat Buton Suku Cia-Cia Di Samarinda. eJournal Sosiatri-Sosiologi, 7(1):88102

23. Puspitasari S. \& Yossi F.(2017). Pengetahuan, Sumber Informasi, Umur, Kepercayaan terhadap Perilaku Personal Hygiene pada Remaja Putri di SMAN 1 Megamendung Bogor.Jurnal Ilmu Kesehatan Masyarakat, 6(4):201-205

24. Santina, T., Wehbe, N., Ziade, F.M., \& Nehme, M. (2013). Assessment of beliefs and practices relating to menstrual hygiene of adolescent girls in Lebanon. International Journal of Health Sciences and Research, 75-88.

25. Santoso, H.B.2008. Ragam dan Khasiat Tanaman Obat.Jakarta : Agromedia Pustaka. Cetakan I.

26. Sapkota D, Sharma D, Budhathoki SS, Khanal VK, \& Pokharel. (2013). HP/ Knowledge and practices regarding menstruation among school going adolescents of rural Nepal. Journal of Kathmandu Medical College.2(3):122-128

27. Schoorl, J.W. (2003).Masyarakat, Sejarah dan Budaya Buton.Jakarta : Djambatan

28. Sheppard,B.H., Hartwick, J., \& Warshaw, P.R. (1988). The Theory of Reasoned Action: A MetaAnalysis of Past Research with Recommendations for Modifications and Future Research. Journal of Consumer Research, 15(3):325-343

29. Simanjuntak, P. (2012). Studi Kimia Dan Farmakologi Tanaman Kunyit (Curcuma Longa L) Sebagai Tumbuhan Obat Serbaguna. Jurnal Ilmu Pertanian, 17(2):103-107.

30. Subaris, H. 2016. Promosi Kesehatan, Pemberdayaan Masyarakat, Dan Modal Sosial. Nuha Medika.

31. Thoyyib, T. (2016). Pengetahuan Personal Hygiene Santri Di Pondok Salafiyah Darul Falah

Desa Depok Kecamatan Panggul Kabupaten Trenggalek (Thesis), Ponorogo: Universitas Muhammdiyah ponorogo.

32. Umadevi, M. Pushpa, R. Sampathkumar, K.P. Debjit Bhowmik., 2012. Beras Tradisional Tanaman Obat Di India. Jurnal Farmakoknosi Dan Fitokimia, $1(1): 35$. 